\title{
AMERICAN AVOCET OBSERVATIONS AND BREEDING OCCURRENCES IN THE BOREAL REGIONS OF ALBERTA: $1999-2003$
}

GERARD W. BEYERSBERGEN, Environment Canada, Canadian Wildlife Service, Environmental Conservation Branch, Edmonton, AB T6B2X3, E-mail: <gerard.beyersbergen@ec.gc.ca>

The American Avocet (Fig. 1) is a large shorebird of the prairies, and the northern limit of the breeding range is currently defined as an area just south of $54^{\circ} \mathrm{N}$ latitude in central Alberta (Fig. 2), which is the approximate latitude of Edmonton. ${ }^{7}$ A historic record shows that they have bred farther north to the southern Mackenzie area near Rae, NWT. ${ }^{4}$ Specimens collected in the nineteenth century from Fort Resolution, NWT, and Fort Chipewyan and Lesser Slave Lake in Alberta showed that they ranged farther north than their current distribution. ${ }^{4}$ Francis and Lumbis reported breeding of avocets on the Syncrude site, near Ft. McMurray, with production of young in 1977 and $1978 .{ }^{3}$ Gulley recorded a number of observations of American Avocets north of Fort McMurray primarily in May of 1977 and 1980 - 1982.5 Kuyt reported an observation by a local resident of a flock of 12 avocets on wetlands $35 \mathrm{~km}$ northwest of Fort Smith, NWT, in the summer of $1988 .{ }^{6}$ In the Atlas of Breeding Birds of Alberta, Semenchuk noted extralimital breeding of the American Avocet in the McLennan area west of Lesser Slave Lake, ${ }^{8}$ while the Second edition of the atlas indicates confirmed breeding farther northwest near the town of Peace River. ${ }^{2}$

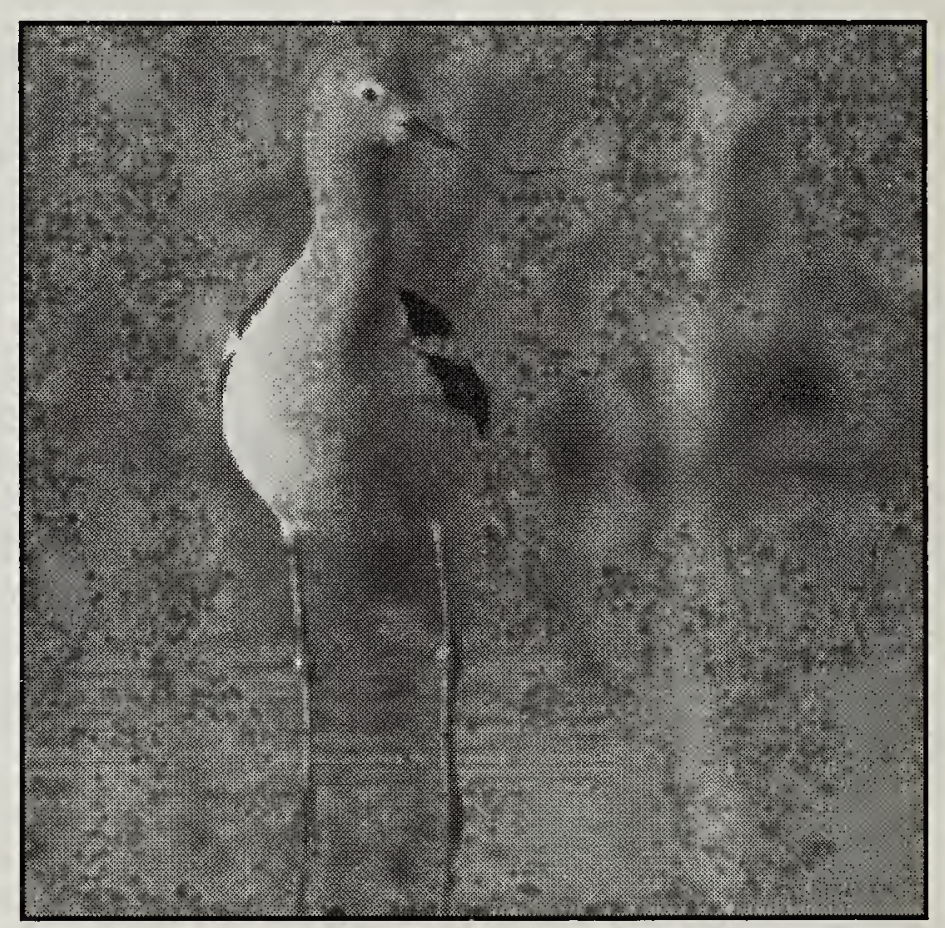

Figure 1. American Avocet.

Gerard W. Beyersbergen

I conducted shorebird surveys throughout the boreal regions of Alberta from 1999 through 2003 (Fig. 2). During these surveys, American Avocets were observed nesting (Fig. 3) or were otherwise present in the wetland landscape. Surveys were conducted aerially at Hay-Zama Lakes and the Peace-Athabasca Delta and on the ground at Kimiwan Lake and in the High Level area.

\section{Peace Athabasca Delta}

My first recorded observations of American Avocets in the boreal region 


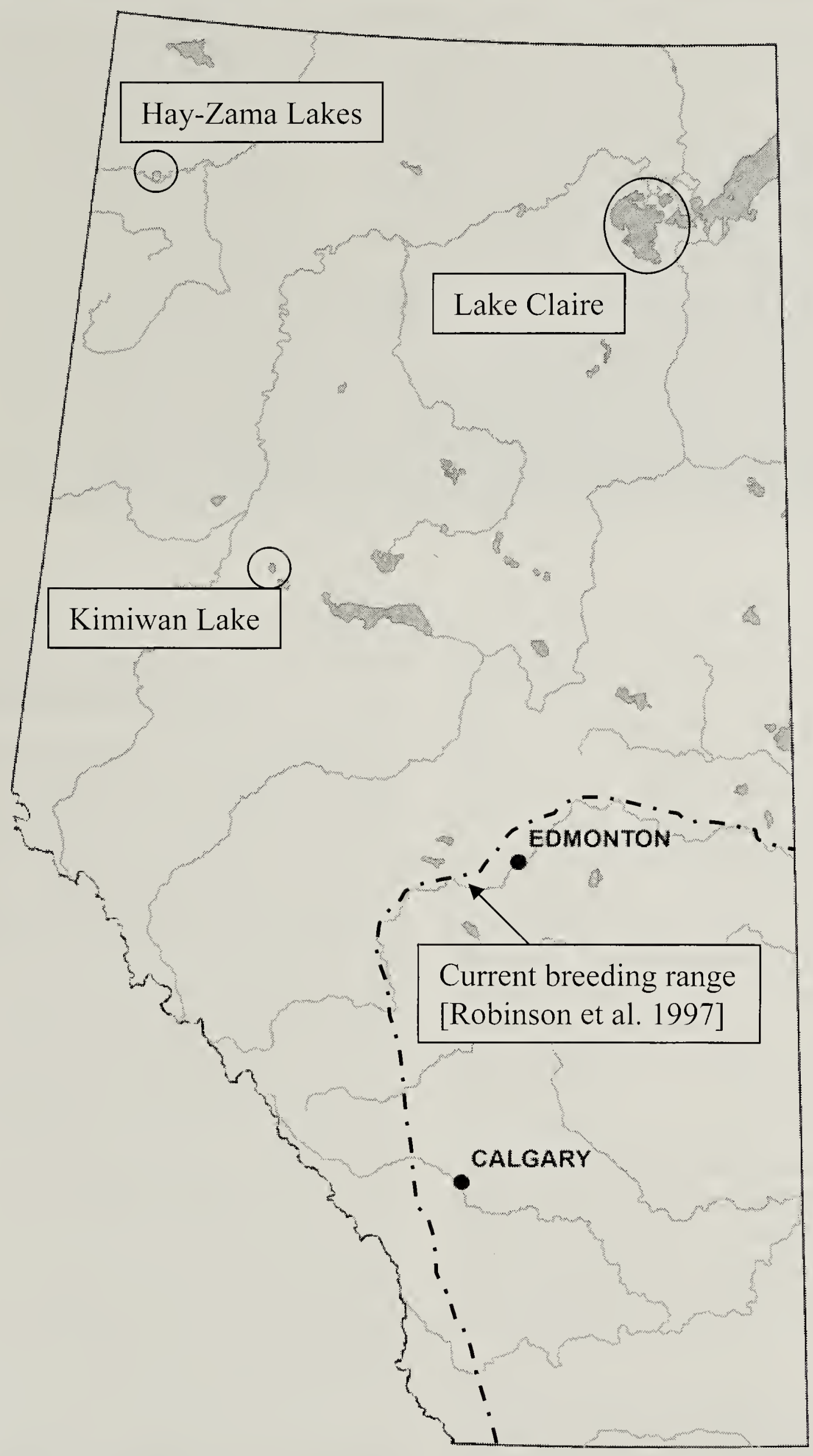

Figure 2. Northern limit of the American Avocet breeding range and extensions in the boreal region of Alberta.

Gillian Turney 


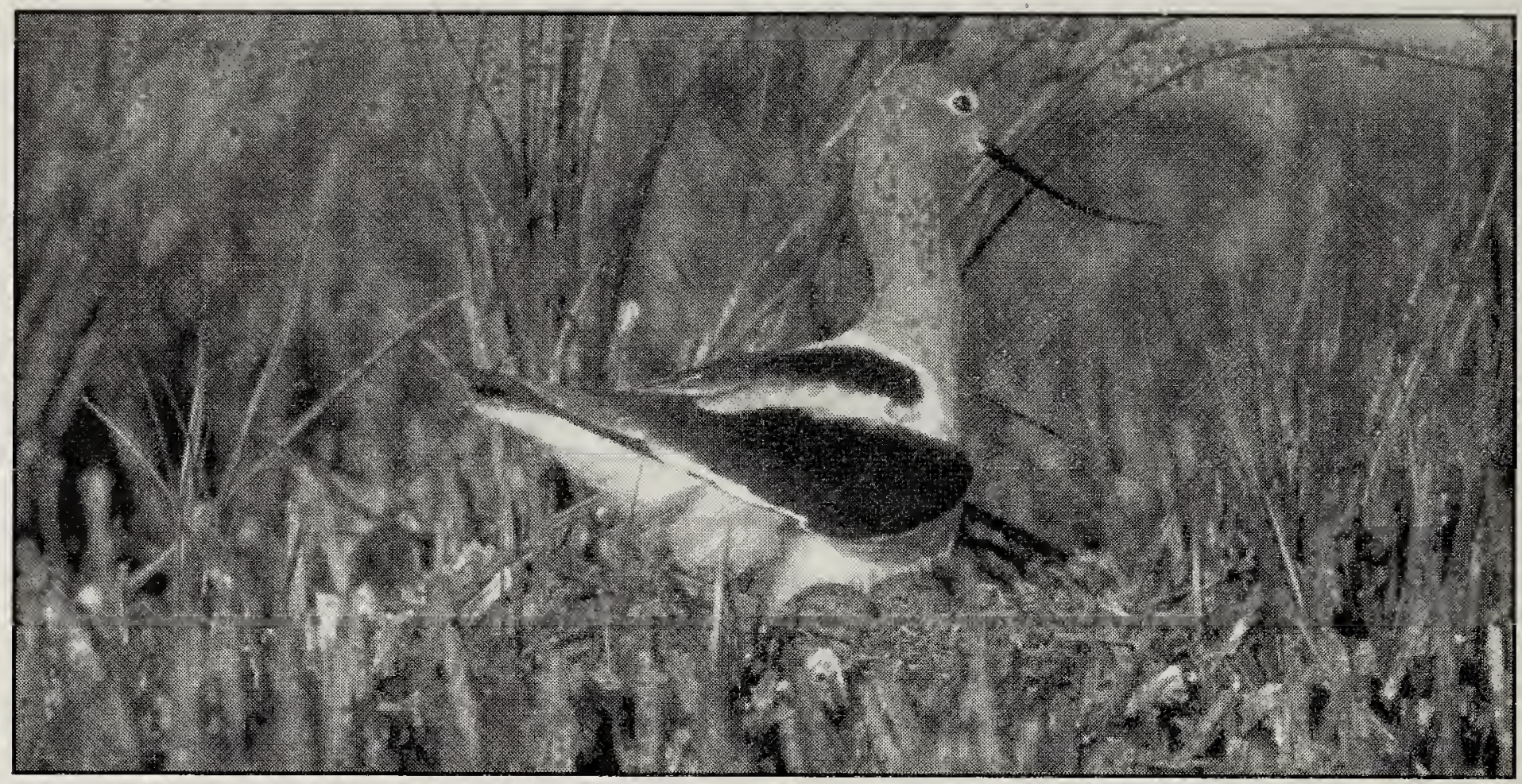

Figure 3. American Avocet on nest.

Gerard W. Beyersbergen

occurred during aerial surveys of the Peace Athabasca Delta in the spring and summer of $1999 .{ }^{1}$ A complete circuit of the lakes in the delta required 2 days of flying, and four sets of these surveys were conducted that year. Observations were made in May and July, and the bulk of the observations of American Avocet occurred in basins surrounding Lake Claire (Table 1) in the western quadrant of the Peace Athabasca Delta. The Birch River delta is located on the southwest corner of Lake Claire; Welstead Lake and a basin locally referred to as Frog Lake are in the southeast, and the wetland basin locally referred to as Lynx Stand are in the northeast quadrant of Lake Claire. All of these basins had shallow water zones along bare or sparsely vegetated shorelines, which is the preferred habitat for American Avocets for feeding and nesting.

In total, 51 adults were observed in the first survey, and observations dropped by nearly half in the second survey, 6 days later (Table 1). I assumed that many of these adults had initiated nesting, were sitting on nests away from the shoreline, and were not flushed by the aircraft and therefore could not be observed.
However, some of these adults may have continued farther north into the NWT as was noted in earlier years by Kuyt. ${ }^{6}$

The first fall survey in late July found 91 American Avocets on the same wetlands where avocets had been observed in the spring period (Table 1). This is a minimum estimate of observed birds because aerial surveys of Welstead Lake recorded only one American Avocet, while five birds were observed in the same area during a ground check on the same day. From the air, no differentiation was made as to the age category of these birds. It is likely that a number of these birds may have been young of the year resulting from the breeding efforts of some of the 27 to 51 adults observed during the two spring surveys. Successful nesting in the Peace Athabasca Delta was confirmed through observations of adults with flightless young at Lynx Stand basin during 1999 field studies by another researcher in the area (L. Carbyn, Canadian Wildlife Service, pers. comm.). The final survey was completed on 11 August, when only one American Avocet remained.

Waterfowl surveys conducted in the Peace Athabasca Delta in the spring of 
Table 1. American Avocet observations during the 1999 aerial shorebird surveys of the Peace Athabasca Delta.

\begin{tabular}{|c|c|c|c|}
\hline Waterbody & Date & $\begin{array}{l}\text { Number of } \\
\text { birds }\end{array}$ & Comment \\
\hline \multicolumn{4}{|l|}{ Survey One } \\
\hline Lynx Stand basin & May 24 & 24 & $\begin{array}{l}\text { Flocked along south } \\
\text { shore of basin }\end{array}$ \\
\hline Birch River delta wetlands & May 25 & 2 & Pair \\
\hline Welstead Lake & May 25 & 25 & $\begin{array}{l}\text { Flock, not differentiated } \\
\text { into pairs during survey }\end{array}$ \\
\hline Survey total & & 51 & \\
\hline \multicolumn{4}{|l|}{ Survey Two } \\
\hline Lynx Stand basin & May 30 & 14 & $\begin{array}{l}2 \text { pairs, group of } 10 \\
\text { (pairs) }\end{array}$ \\
\hline Birch River delta wetlands & May 31 & 8 & 4 pairs \\
\hline Welstead Lake & May 31 & 3 & Pair and lone adult \\
\hline Frog Lake & May 31 & 2 & Pair \\
\hline Survey total & & 27 & \\
\hline \multicolumn{4}{|l|}{ Survey Three } \\
\hline Lynx Stand basin & July 24 & 7 & 2 single birds, group of 5 \\
\hline Mamawi Lake & July 24 & 1 & $\begin{array}{l}\text { Single bird on small } \\
\text { basin off main lake }\end{array}$ \\
\hline Frog Lake & July 25 & 17 & $\begin{array}{l}\text { Single bird, group of } 4 \\
\text { and flock of } 12\end{array}$ \\
\hline Welstead Lake & July 25 & 1 & Single bird \\
\hline Birch River delta wetlands & July 25 & 65 & $\begin{array}{l}\text { Scattered along } \\
\text { shoreline of south basin } \\
\text { in delta }\end{array}$ \\
\hline Survey total & & 91 & \\
\hline \multicolumn{4}{|l|}{ Survey Four } \\
\hline Birch River delta wetlands & August 11 & 1 & Single bird \\
\hline Survey total & & 1 & \\
\hline
\end{tabular}

2000 recorded observations of American Avocets on delta wetlands (M. Gendron, Ducks Unlimited Canada, pers. comm.), confirming continued use of the delta.

\section{Hay-Zama Lakes/High Level}

The first reported observations of American Avocets on Hay-Zama Lakes were made during an airboat survey of the complex on 21 June 2001 (K. Morton, Alberta Sustainable Resource Development, pers. comm.). Morton found three pairs nesting on the complex, which included a pair with a nest of four eggs and an adult with two young.

In 2001, during two aerial waterfowl surveys of the entire Hay-Zama Lakes complex by K. Wright, Alberta Conservation Association, I participated as an observer to check for shorebird use of the area as a migration stopover site (unpublished data). Thousands of shorebirds were observed, but no 
Table 2. American Avocet observations during the 2002 aerial shorebird surveys of the Hay-Zama wetland complex.

\begin{tabular}{|c|c|c|c|}
\hline Waterbody & Date & $\begin{array}{c}\text { Number of } \\
\text { birds }\end{array}$ & Comment \\
\hline \multicolumn{4}{|l|}{ Survey One } \\
\hline Sand Lake & May 20 & 5 & $\begin{array}{l}\text { Group of three and a pair on NE } \\
\text { shoreline }\end{array}$ \\
\hline Slough 3 & May 20 & 6 & $\begin{array}{l}\text { Three pairs scattered along the } \\
\text { south shoreline }\end{array}$ \\
\hline North Zama Lake & May 20 & 3 & $\begin{array}{l}\text { A pair and single adult on the east } \\
\text { shoreline }\end{array}$ \\
\hline Survey total & & 14 & \\
\hline \multicolumn{4}{|l|}{ Survey Two } \\
\hline Duck Lake & August 13 & 10 & $\begin{array}{l}\text { Group of } 10 \text { birds along the } \\
\text { shoreline }\end{array}$ \\
\hline West Hay Lake & August 13 & 1 & Lone bird on east shoreline \\
\hline Survey total & & 11 & \\
\hline
\end{tabular}

American Avocets were detected from the aircraft in either the spring or fall flight.

The shorebird observer effort was repeated as part of the waterfowl survey in the spring of 2002. A minimum of 14 adult American Avocets were observed from the air (Table 2). Only those birds that flushed or were highly visible on the bare shoreline would be detected, so any birds that remained roosting or were nesting, especially in the shoreline vegetation, would not have been recorded.

A survey of the entire complex was conducted in August by a team of two observers in a rotary-winged aircraft on 13 August 2002. In total, 11 American Avocets were recorded but no age class was distinguished, so it is unknown if breeding had occurred that year on the wetland complex (Table 2).

Two aerial shorebird surveys were conducted on Hay-Zama Lakes in May 2003, but the complex was completely flooded well into the willows, and suitable shorebird habitat was unavailable that spring. However, during a tour of the area around High Level for other waterbird species, a pair of American Avocets was observed on 16 May 2003 on Linton Lake, which is located about $4 \mathrm{~km}$ southwest of La Crete.

\section{Kimiwan Lake}

Kimiwan Lake was surveyed as part of the prairie-wide aerial shorebird surveys in 1987 (A.R. Smith and H.L. Dickson, unpublished data), and American Avocets were reported on the lake during the spring survey on 21 May when six adults were observed. The lake was surveyed twice again in the fall, and on 4 September, two avocets were observed.

Two partial surveys were conducted on Kimiwan Lake in 2001, and the area was scanned from select vantage points on the south end at the boardwalk and from the west shore near the channel outlet. The highest number of American Avocets was recorded during the second survey (Table 3 ). No effort was made to search for nesting birds. However, given the number of birds present on the lake, it is quite likely that nesting did occur that year. 
Table 3. American Avocet observations during the 2001-03 ground shorebird surveys of Kimiwan Lake.

\begin{tabular}{|c|c|c|c|c|c|}
\hline Year & \multicolumn{5}{|c|}{ Survey Date } \\
\hline \multirow[t]{2}{*}{2001} & & & & May 22 & May 30 \\
\hline & & & & 62 & 180 \\
\hline \multirow[t]{2}{*}{2002} & & May 16 & May 19 & May 22 & \\
\hline & & 302 & 1066 & 1081 & \\
\hline \multirow[t]{2}{*}{2003} & May 14 & May 19 & & May 24 & May 27 \\
\hline & 10 & 9 & & 9 & 0 \\
\hline
\end{tabular}

A 2-year study of shorebird migration staging on Kimiwan Lake was initiated in May 2002. The entire perimeter of the lake was checked on foot and by ATV, where feasible. Wide expanses of open mudflats were present around the waterbody, and conditions were ideal for staging migrant shorebirds. The survey period was shortened because of logistical problems, and the survey effort concluded on 22 May. American Avocets were present on the lake in large numbers with a peak count of 1081 adults occurring on the last survey day (Table 3 ). The number of avocets did not vary much between the last two survey days, so it is likely that the maximum number of birds that would use the lake that year were recorded on the last survey. Numerous nesting pairs were observed throughout the three surveys, but no nests were physically checked or disturbed.

Precipitation was low in the winter of 2002-2003 in the Kimiwan Lake area, and water levels dropped in the lake. The bare shoreline from the previous spring was completely vegetated with a variety of unidentified herbaceous plants, and suitable shorebird habitat was at a premium. Migrant shorebird numbers were the highest in 2003 during the first survey on 14 May and declined during successive surveys (unpublished data). American Avocet numbers were down considerably from the previous spring, with a peak daily count of only 10 adults being recorded that spring (Table 3 ). Nesting may have occurred at the lake but was not recorded.

The occurrence of nesting birds has occurred for enough years and with enough regularity that it is clear that the breeding range of the species has expanded beyond the current estimated range near Edmonton. Some of these occurrences may have been a result of poor wetland conditions on the prairies, but the regularity and number of consistent observations in the boreal region indicate that a breeding tradition has been established in the boreal region.

\section{Acknowledgments}

Thanks to those individuals, as noted in the article, who provided observations of American Avocets during the course of their work in the boreal region. Special thanks to Ken Wright for allowing me to ride along during his surveys of the HayZama Lakes wetland complex. Thanks to Gillian Turney for fitting me into her busy schedule and producing the figure. Helpful comments were provided by W. A. Calvert. 
1. BEYERSBERGEN, G.W. 2004. An investigation of migrant shorebird use of the Peace-Athabasca Delta, Alberta in 1999. In: Environment Canada, Northern Rivers Ecosystem Initiative: Collective Findings (CDROM). Compiled by F.M. Conly, Saskatoon, SK, 2004. (With Alberta Environment).

2. FEDERATION OF ALBERTA NATURALISTS. 2007. The Atlas of Breeding Birds of Alberta. A Second Look. Federation of Alberta Naturalists, Edmonton, Alberta.

3. FRANCIS, J. and K. LUMBIS. 1979. Habitat relationships and management of terrestrial birds in northeastern Alberta. Alberta Oil Sands Environmental Research Program, Report No. 78. Edmonton, Alberta.

4. GODFREY, W.E. 1986. The Birds of Canada. National Museum of Natural Sciences. National Museums of Canada. Ottawa, Ontario.
5. GULLEY, J.R. 1983. Unusual avian observations for the Fort McMurray, Alberta area, 1976-1982. Alberta Naturalist 13(2): 45-47.

6. KUYT, E. 1989. A recent record of American Avocet in the Northwest Territories. Alberta Naturalist $19(1): 27-29$.

7. ROBINSON, J. A., L. W. ORING, J. P. SKORUPA, and R. BOETTCHER. 1997. American Avocet (Recurvirostra americana), The Birds of North America Online (A. Poole, Ed.). Cornell Lab of Ornithology, Ithaca, New York. Retrieved from the Birds of North America Online: http://bna.birds.cornell. edu/bna/species/275

8. SEMENCHUK, G. P. (editor) 1992. The Atlas of Breeding Birds of Alberta. Federation of Alberta Naturalists, Edmonton, Alberta.

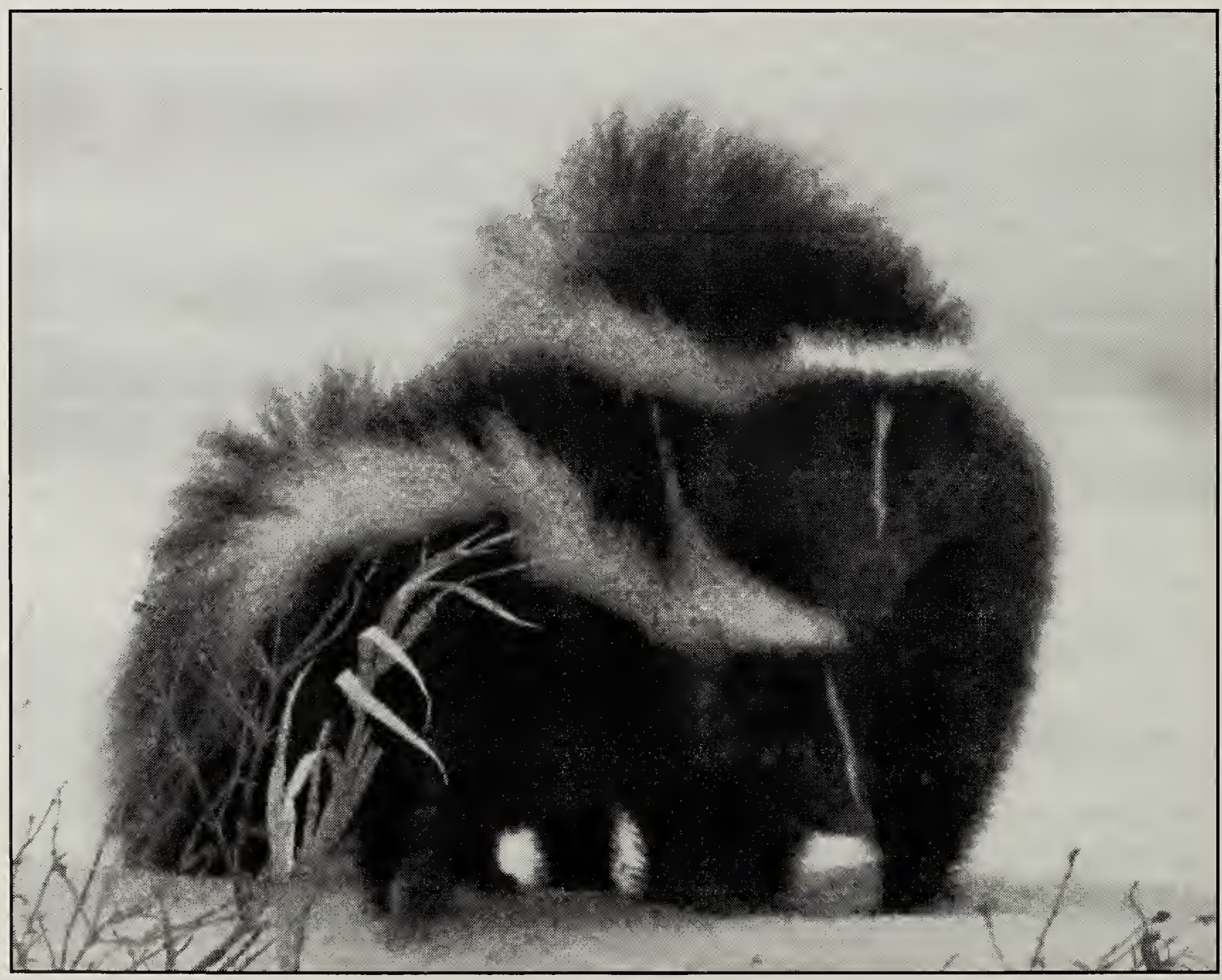

Striped skunks in winter.

Christian Artuso 